\title{
PREDATORS ON MARINE FISH FARMS IN TASMANIA
}

\author{
by David Pemberton, Nigel Brothers and Geof Copson
}

(with two tables)

PeMberton, D., Brothers, N. \& COPSON, G., 1991 (20:xii): Predators on marine fish farms in Tasmania. Pap. Proc. R. Soc. Tasm. 125: 33-35. https://doi.org/10.26749/rstpp.125.33 ISSN 0080-4703. Ocean Sciences Center, Memorial University of

Newfoundland, St Johns, Newfoundland, Canada A1C 5 S7 (DP); Department of Parks, Wildlife and Heritage, 134 Macquarie Street, Hobart, Tasmania, Australia 7000.

Marine aquaculture of the salmonids atlantic salmon (Salmo salar) and rainbow trout (Salmo gairdnert) is a rapidly growing industry in Tasmania. There is considerable damage to the fish on these farms by avian and mammalian predators. The mode by which these predators attack the fish on the farms allows for practical methods to reduce the loss of fish. Physically excluding predators from the fish is ultimately the only way to prevent this loss entirely. A total of six predators that interact with the farms are described and the necessity for the protection methods to be incorporated into the design of the farms prior to farm development is emphasised.

Key Words: aquaculture, salmonids, seal, silver gull, cormorant, water rat, sea eagle, management.

\section{INTRODUCTION}

Marine aquaculture of the salmonids atlantic salmon (Salmo salar) and rainbow trout (Salmogairdneri) is a rapidly growing industry in Tasmania, with 19 operational farms in 1990. These farms are located in southeastern Tasmania ( 16 farms) and in Macquarie Harbour (three farms) in the southwest of the state. The farms vary in size, producing from 100 to 250 tonnes of fish per year. The fish are farmed in pens, termed "polar circles", that are constructed with polypipe. They vary from 20 to $60 \mathrm{~m}$ in diameter and have a net hanging to approximately $5 \mathrm{~m}$ deep. These pens are stocked with 10 to $15 \mathrm{~kg} / \mathrm{m}^{3}$ of fish which, depending on the time of year, are between 0.05 and $0.4 \mathrm{~m}$ in length. These large concentrations of fish attract many predators.

Finfish aquaculture also occurs in Western Australia and South Australia, and will probably spread to others areas of the country. Neither in Tasmania nor overseas (Ross 1988) has the problem of predators been taken into account prior to aquaculture establishment. Consequently, the impacts of the predators on the fish farms are often difficult to control because of inappropriate siting of the farms, design faults and high unplanned costs.

It is the aim of this paper to identify the avian and mammalian predators that come into conflict with fish farms in Tasmania and to discuss practical ways to reduce their impact.

\section{METHODS}

A total of seven fish farms in southeastern Tasmania were surveyed to establish what predators were causing problems and the nature of these problems. Farmers were interviewed and direct observations were made of predators of the farms from 1987 to 1990 . The species of predators involved in the interaction, how they entered the nets and any action taken by the farmers to prevent entry were recorded. Because farmers tend to blame certain predators for damage to fish when these predators were not actually observed causing the damage, it was necessary for the authors to verify all information obtained from farmers. Only those records where the predators were seen in the fish pens catching fish or attempting to, or where the damage to the fish was characteristic of a certain predator, were accepted. Predation by seals and cormorants could be identified by the damage to the fish. Those attacked by seals have parallel scrapes and punctate holes caused by the seals canines. Cormorants jab and grab at fish with their beaks, resulting in either small single punctate wounds or single striations.

The nets that hang from the pens to contain the fish are referred to as containment nets, whilst nets hung outside the containment net to prevent attack by predators are referred to as protection nets.

\section{OBSERVATION ON PREDATION}

A total of six species of predators were found to interact to some degree with fish farms. These included Australian fur seals (Arctocephalus pusillus doriferus), silver gulls (Larus novaehollandiae), water rats (Hydromys chrysogaster), two cormorant species (Phalacrocorax carbo, P. fuscescens) and white-bellied sea eagles (Haliaeetus leucogaster).

The degree of interaction varied. All seven farms incurred problems with seals and silver gulls, four with water rats, three with sea eagles and two with cormorants. The great cormorant $(P$. carbo) was a confirmed predator on fish farms, and there were occasional reports by farmers of a smaller species of cormorant that attacked fish. This was probably the black-faced cormorant ( $P$. fuscescens) which is common in these waters.

Seals, cormorants and white-bellied sea eagles were the only predators observed capturing fish out of the pens. Though silver gulls and water rats have the ability to capture fish, this was never observed. Silver gulls fed on the fish food as it was distributed by automatic feeders over the pens. In addition, while waiting for the periodic release of the feed they defecated in the pens, thereby producing a hygiene problem.

Seals gained access to the fish by penetrating the holding net. This resulted in holes varying in size from 0.05 to $3 \mathrm{~m}$. Many seal attacks not only damaged fish but also resulted in the release of fish. Gulls, water rats, cormorants and sea eagles all entered the pen from above when the fish were exposed (table 1). Though water rats could chew through the nets and use existing holes, this was never recorded. Sea eagles were observed perching on the perimeter of the $20 \mathrm{~m}$ 
TABLE 1

Characteristics of predators on seven fish farms

\begin{tabular}{|c|c|c|c|c|}
\hline \multirow[t]{2}{*}{ Predator } & \multicolumn{2}{|c|}{ Orientation of entry into net } & \multirow{2}{*}{$\begin{array}{l}\text { Maximum } \\
\text { prey size* } \\
\quad(\mathrm{cm})\end{array}$} & \multirow{2}{*}{$\begin{array}{l}\text { Foraging } \\
\text { technique }\end{array}$} \\
\hline & Side & Surface & & \\
\hline \multicolumn{5}{|l|}{ Seal } \\
\hline Arctocephalus pusillus doriferus & $\mathrm{x}$ & - & 80 & Pursuit diving \\
\hline \multicolumn{5}{|l|}{ Silver gull $T$} \\
\hline Larus novaehollandiae & - & $\mathrm{x}$ & 10 & Surface seize and dipping \\
\hline \multicolumn{5}{|l|}{ Water rat } \\
\hline Hydromys chrysogaster & $?$ & $\mathrm{x}$ & 36 & Pursuit diving \\
\hline \multicolumn{5}{|l|}{ Great cormorant } \\
\hline Phalacrocorax carbo & $x^{\dagger}$ & $\mathrm{x}$ & 40 & Pursuit diving \\
\hline \multicolumn{5}{|l|}{ B lack-faced cormorant } \\
\hline P. fuscescens & $x^{\dagger}$ & $\mathrm{x}$ & 11 & Pursuit diving \\
\hline \multicolumn{5}{|l|}{ Sea eagle } \\
\hline Haliaeetus leucogaster & - & $\mathrm{x}$ & 40 & Surface plunging \\
\hline
\end{tabular}

* Data sources: seals (pers. obs.), water rats (Woollard et al. 1978, Watts \& Aslin 1981), silver gulls (pers. obs.), cormorants (Miller 1979, Lalas 1983), sea eagles (N. Mooney, pers. comm.)

$\uparrow$ Cormorants do seize fish through the net but do not penetrate into the pen.

TABLE 2

Number of fish farms in Tasmania that used various methods to reduce the impact of predators

\begin{tabular}{lcccccc}
\hline Predator & Shooting & $\begin{array}{c}\text { Capture and } \\
\text { removal }\end{array}$ & $\begin{array}{c}\text { Protection } \\
\text { nets }\end{array}$ & Emetics & Scare crackers & No action \\
\hline Seals & 7 & - & 6 & 3 & 4 & - \\
Gulls & - & - & 7 & - & 2 & - \\
Water rats & 1 & 2 & - & - & - & 1 \\
Cormorants & 2 & - & - & - & - & - \\
Sea eagles & - & - & - & - & - & 3 \\
\hline
\end{tabular}

* Species names as in table 1.

diameter pens but were never actually seen to take fish, although they made frequent attempts. The reports of sea eagles catching fish were only in association with the larger $60 \mathrm{~m}$ diameter polar circle.

\section{MINIMISATION OF PREDATION}

This study identified six species of birds and mammals that prey on the fish in fish farms and showed that all marine fish farms are vulnerable to predation by these animals.

The farms surveyed all occur in the marine environment in waters between 20 and $30 \mathrm{~m}$ deep. They are sited in sheltered bays within $5 \mathrm{~km}$ of the open ocean. The predators described either live in these bays (water rats) or forage daily in these areas (seals, silver gulls, sea eagles and cormorants). These predators also have a foraging strategy, dietary preference and prey handling capacity which allows them to exploit farm fish (table 1). The way in which they exploit it varies and, in response, so does the protection method recommended. Protection methods used for the various predators are shown in table 2.
Seals charge the net (observed on six occasions), ram into it, grab at the fish and tear holes in the net. They are the only predator that actually damages the subsurface net to any great extent and, hence, the protection measures used are fundamentally different from those implemented for the other predators. Large sharks were recorded twice as the cause of large $(1.5 \mathrm{~m})$ tears in the containment nets. One of these attacks was by a thresher shark (Alopias vulpinus).

The strength and weight of the seals, and the speed at which they attacked pens meant that the protection system had to be extremely robust. Polyethylene protection nets, with strands $4 \mathrm{~mm}$ in diameter, stop seals, but the preferred option of wire netting (Boral Cyclone, pig mesh) is probably more effective (Pemberton \& Shaughnessy, pers. comm.). Two deterrents, explosive seal crackers and emetics, were used by some farmers to prevent or reduce seal attacks (table 2). The seal crackers are waterproof explosives that are detonated in the vicinity of the individual seals to scare them into leaving the farm area. The emetics are deployed in baits, in an attempt to induce a conditioned food aversion in the seals to salmon and trout. Both these methods are effective in reducing the rate of attack but do not 
prevent every attack (Pemberton \& Shaughnessy, pers. comm.).

As silver gulls, cormorants and sea eagles forage by plunging into the pens from above, they were easily deterred by placing netting over the pens. Some farmers strung lengths of monofilament across the pens to prevent gulls from landing on the water. This proved to be futile and netting is effective only if it is strung over the top of the cage without any gaps. Gaps in the netting are soon exploited by both silver gulls and cormorants. Bird fright crackers which explode in the air were used by two farms as a trial in an attempt to frighten gulls, but this proved unsuccessful as the birds would return within hours. Cormorants also attacked the caged fish under the water through the containment nets. This form of attack is prevented by the outer protection nets described above, deployed to exclude the seals from the pens.

A more lateral approach was taken with water rats which, by virtue of their small size and agiliry, are far more difficult to prevent from entering the pens. The option of systematically removing water rats from the farms and relocating them in suitable habitats was discarded because it is likely that this would only be a temporary solution, as dispersal of water rats into the resource-rich area of the fish farm is likely to take place. In addition, removing animals to another area merely places pressure on the receiving population of water rats. Instead, the aggressive territoriality of water rats and their use of distinct feeding platforms was exploited (Watts \& Aslin 1981). The farmers now place dead salmonid fish at set feeding sites. The rationale of this method is to supplement the diet of the resident water rats to reduce their impact on the penned fish, residents who, by maintaining their territorial boundaries, prevent the immigration of additional individuals from adjacent areas. There has not been any quantitative assessment of the efficacy of this method, but the farmers have observed water rats taking proffered fish and are satisfied that their impact on the fish mortalities has decreased.

Both the common dolphin (Delphinus delphis) and bottlenose dolphins (Tursiops truncatus) have been observed around and within the lease area of the fish farms. They have never attacked the fish in the pens and do not appear to cause the fish any disturbance. Therefore they are not considered to be a problem. Similarly, when a fish farm suffered damage to a pen caused by a southern right whale (Eubalaena glacialis), it was apparent that the damage was the result of the whale colliding with the pen, not of the animal attacking the penned fish.

All the predators described here, except the great cormorant, are wholly or partly protected under the Tasmanian National Parks and Wildlife Act 1970, and therefore shooting or capture can only be done under permit. Shooting as a method of control is costly and ineffective. Despite the wide use of 24-hour armed guards on the farms, deploying both crackers and shooting (table 2), the predators persist in feeding in the pens. There was only a $44 \%$ success rate at scaring seals away from the pens by shooting at them, and less than $10 \%$ of the attacking animals were shot (Pemberton \& Shaughnessy, submitted).
The only practical way to reduce the impact of the predators on the fish farms is to physically exclude them. The farmers have to assess the losses caused by the predators against the cost and maintenance of exclusion methods. As a result, most farmers deploy physical exclusion nets for both volant and underwater predators (table 2). The geographical position of the farms in relation to the predators should also be taken into account when planning aquaculture development. The two farms that suffer the most damage from seals in Tasmania are located closest to seal haulout sites (Pemberton \& Shaughnessy, submitted). A similar situation would probably occur with farms close to breeding sites of colonial breeding birds such as cormorants and gulls.

As the fish farming industry develops, so will the design of the fish cages. Changes in design may open new avenues for the predators to exploit. For example, there is a plan to increase the size and structure of pens, which will make the fish more vulnerable to sea eagles, since these require space in which to plunge, feed and take off again. To date, there have been no reported problems with white-faced herons (Ardea novaehollandiae), kelp gulls (Larus dominicanus) or dominican gulls (L. pacificus), which may be, in part, the result of cage design. Any change in cage design must take into account the method by which predators forage.

\section{ACKNOWLEDGEMENTS}

This study was funded jointly by the Tasmanian Government and SALTAS Shareholders, the Princess Melikoff Trust and an Australian National Parks and Wildlife States Cooperative Assistant Program. The authors also acknowledge Peter Shaughnessy, Rosemary Gales and all the fish farmers who assisted with the study. Comments on a draft of the manuscript by Deane Renouf improved the final product. Peter Shaughnessy is thanked for his constructive criticism of the manuscript.

\section{REFERENCES}

LAI.AS, C., 1983: Feeding ecology of New Zealand marine shags. Unpubl. PhD thesis, University of Otago, New Zealand.

Milier, B., 1979: Ecology of the Little Black Cormorant, Phalacrocorax sulcirostris and Little Pied Cormorant, $P$. melanoleucos, in inland New South Wales: food and feeding habits. Aust. Wildl. Res. 6: 79-95.

PemberTon, D., 1989: The interaction between seals and fish farms in Tasmania. Unpubl. rep.Tasmanian Department of Lands, Parks and Wildlife.

Ross, A., 1988: Controlling nature's predators on fish farms. Report for the Marine Conservation Society, Ross-on-Wye, England.

WATIS, C.H.S. \& AsIIN, H.J., 1981: THE RODENTS OF AUSTRALLA. Angus and Robertson, Australia.

WoOliard, P., VestJens, W.J.M. \& Macil.AN, L., 1978: The ecology of the eastern water rat, Hydromys chrysogaster at Griffith, N.S.W.: food and feeding habits. Aust. Wildl. Res. 5:59-73.

(accepted 11 November 1991) 